Rev. Daniel Dzikiewicz

\title{
The verse of Gen 1, 1: a subordinate or principal clause? \\ A Contribution to the Discussion \\ on the Syntax of the First Sentence of the Hebrew Bible
}

This article is devoted to the syntax issue of Gen 1, 1, which is one of the most discussed Old Testament passages. The biblists' views on it are still divided. According to some, this is an independent statement (status absolutus), while others maintain that this passus is a subordinate sequence (status constructus) to the text of Gen 1, 2-3. They justify their opinions with a variety of arguments: philological-linguistic, exegetical, literary, theological etc. But these are not the justifications that will decide the case. Therefore the present article proposes another argument - contextual. Nevertheless the context is an indispensable element of understanding each literary unit. In this case however it is not about the literary context, but about the historical one, because the causal factor of writing the text Gen 1, 1-2, 4a throws some light on the syntactical problem of verse Gen 1, 1.

Key words: Book of Genesis, syntax, sentence superior, subordinate clause, context, creation, chaos, Babylonian captivity. 


\section{Preface}

Gen 1, 1 is one of the most important ${ }^{1}$, but also one of the most doubtful texts of the Old Testament ${ }^{2}$. It is a kind of exegetes' crossword and crossroads, a philological and theological problems interact and paradigm, an intricate dispute, in which it is impossible to bet ${ }^{3}$. In short, the real-crux interpretum.

In the history of exegesis there have been a various translations and interpretations of these words. Today the situation is not different. Exegetes' opinion remains diverse too ${ }^{4}$. But all this also has a positive side. It means that the discussion is open.

This article pretends to be namely one of many contributions to further discussion in this matter. In order to achieve the intended purpose, it was divided into two parts. The first part shows the status quaestionis of research on the issue. While the second piece presents an argument that the author's opinion indicates the direction, in which could follow the work of translating of the above mentioned verse. And at the end of the study occurs a summary that recaps the work done.

\section{Status quaestionis of research on the syntax of verse from Gen 1, 1}

There are two main methods of translation of the first verse of the Hebrew Bible. The first convention could be called traditional and the other $-\operatorname{modern}^{5}$. Here are some of the most famous examples. For

1 Even can be said, it is a true biblical's revelation's summa summarum, because it is a tale both quintessential things about God and about the creation: God is the Creator and the universe - creation; cf. M. F. Rooker, Genesis 1:1-3: Creation or Re-Creation? Part 1, „Bibliotheca Sacra“, 1992, no. 149, p. 316.

"[Q]uesti [...] versetti presentano [...] tutta una serie di problemi interpretativi" (W. Brueggemann, Genesi, Strumenti Commentari 9, Torino 2002, p. 49).

Cf. P. Ricœur, Apie vertima, Vilnius 2010, p. 7.

Cf. R. M. Davidson, In the Beginning: How to Interpret Genesis 1, „Dialogue“, 1994, no. 6(3), p. 9-12; J. Lemański, Księga Rodzaju. Rozdziaty 1 - 11. Wstęp, przekład z oryginatu, komentarz, Nowy Komentarz Biblijny Stary Testament I/1, Częstochowa 2013, p. 144-145.

5 The name modern is relative, because it was yet known long before it began what is today known as the modern times (eg. so this text explained in the twelfth century rabbi Ibn Ezra). However, such translation has expanded only in the nineteenth and twentieth century, under the influence of some archaeological discoveries (especially the ancient epic Enuma Elish); cf. S. Łach, Ksiegga Rodzaju. 
better recognition of differences a larger part of the biblical text is given - namely the first two verses of the Book of Genesis.

The examples of the traditional method:

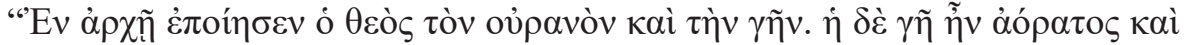

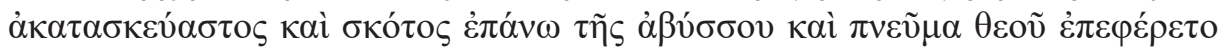

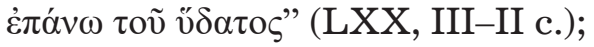

"In principio creavit Deus caelum et terram. Terra autem erat inanis et vacua, et tenebrae super faciem abyssi, et spiritus Dei ferebatur super aquas" (Vulgata, III c.);

"Am Anfang schuf Gott Himmel und Erde. Und die Erde war wüst und leer, und es war finster auf der Tiefe; und der Geist Gottes schwebete auf dem Wasser" (Martin Luther, 1545);

"In the beginning God created the heaven and the earth. And the earth was without form, and void; and darkness was upon the face of the deep. And the Spirit of God moved upon the face of the waters" (King James Bible, 1611).

\section{The examples of the modern method:}

"Lorsque Dieu commença la création du ciel et de la terre, la terre était déserte et vide, et la ténèbre à la surface de l'abîme; le souffle de Dieu plânait à la surface des eaux" (Traduction Ecuménique de la Bible, 1979);

"When God began to create heaven and earth - the earth being unformed and void, with darkness over the surface of the deep and a wind from God sweeping over the water" (New Jewish Publication Society Version, 1985);

"In the beginning when God created the heavens and the earth, the earth was a formless void and darkness covered the face of the deep, while a wind from God swept over the face of the waters" (New Revised Standard Version: Catholic Edition, 1991);

"Quand Élohîm commença à créer les cieux et la terre - or la terre était tohu et bohu, et ténèbre sur la face d'un abysse, et vent d'Élohîm remuant sur la face des eaux" (André Wénin, 2007).

Why is the one text translated in two, not only different, but also contradictory ways? The culprit of this linguistic dialectic is the 
Biblical theology

"simple" ancient biblical Hebrew syntax". It is precisely this "simplicity" thanks, the first linguistic unit of Bible (Gen 1, 1), which is introduced by the Hebrew phrase absolutus) or part of a complex sentence (status constructus) i.e. the piece of Gen $1,1-3^{7}$. The first view is represented by the traditional method of translation, the second by the modern approach. Which version is better? Linguistically both translations are completely valide et licite ${ }^{8}$.

And what arguments adduce the followers of these translations? Their argumentation is diverse. Dominated, however, by linguisticexegetical and theological reasons.

Those who regard Gen 1, 1 as a title or as an independent sentence (status absolutus), they maintain e.g. that it is an anthemic equivalent of the Old Testament confessions of faith in God as the Creator of heaven and earth (cf. Gen 14, 19-22; Ps 115, 15; 121, 2; 124, 8), or cite testimony of LXX, which reads the verse of Gen 1,1 as independent clause, either refer to the so-called the second description of the creation of the world, which also begins with the sentence constitutes a form of title in Gen 2,4a9.

When it comes to followers of other hypotheses, their arguments

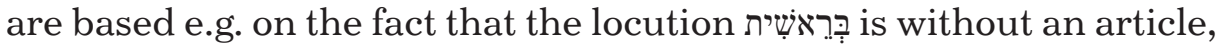
and the lack of which can give the verse Gen 1, 1 a sense of time, which in turn would indicate that the first sentence of the Hebrew Bible is a subsidiaries phrase (status constructus). As evidence they adduce

$6 \quad$ "While the first sentence of the Bible is relatively straightforward in Hebrew, it possesses a subtle ambiguity that makes it difficult to translate" (D. W. Cotter, Genesis, Berit Olam. Studies in Hebrew Narrative and Poetry, Collegeville 2003, p. 12); cf. J. Lemański, Księga..., op. cit., p. 145.

7 Cf. B. S. Childs, Teologia biblica. Antico e Nuovo Testamento, Priemme Theologica, Casale Monferrato 1998, p. 132; J. Lemański, Pięcioksiag dzisiaj, Studia Biblica 4, Kielce 2002, p. 152; J. Lemański, Księga..., op. cit., p. 144-145; V. P. Hamilton, Handbook on the Pentateuch. Genesis. Exodus. Leviticus. Numbers. Deuteronomy, Grand Rapids 1995, p. 30-31; B. Vawter, Genesis, in R. C. Fuller (ed.), A New Catholic Commentary on Holy Scripture, Nashville-Camden - New York $1984^{3}$, p. 173.

8 "Le due versioni sono gramaticalmente possibili" (La Bibbia di Gerusaleme, Bologna $2000^{17}$, p. 35); “Gli studiosi moderni sono ampiamente d'accordo nel sostenere che questo problema non può essere risolto soltanto su una base grammaticale. In effetti, sono possibili entrambe le opinioni [...]" (B. S. Childs, Teologia..., op. cit., p. 132).

$9 \quad$ Cf. J. Lemański, Księga..., op. cit., p. 144-145; P. Morant, Die Anfänge der Menschheit. Eine Auslegung der ersten elf Genesis-Kapitel, Luzern 1960, p. 41-42. 
the beginning of the first sentence of the Babylonian epic Enuma Elish, where the first words mean simply: when at the to ${ }^{10}$.

These two different methods of translation of the verse Gen 1, 1 also contributed to the emergence of two different interpretations of the reality described in the sentence Gen 1,2 . The first interpretation is called the initial chaos theory and the second is named the precreation chaos theory ${ }^{11}$. Proponents of both views hold that the creation of an orderly universe, described in the Gen 1,1-2, 4a, was first preceded by the existence of transitional forms of chaos. It was formed substantially of three elements: of the formlessness, of the darkness and of the deep water.

However, between these two theories there is a fundamental difference. According to the first hypothesis the chaos described in the second verse (Gen 1,2) is a direct consequence God's creative activity outlined in the first line (Gen 1, 1). In other words, the primitive chaos was created by the Lord God ${ }^{12}$. Whereas according to the secondguessing of biblical scholars the initial turmoil in the world (Gen 1, 2 ) existed independently to the creative operation of God referred in the verse Gen $1,1^{13}$.

Which interpretation could be accepted? Usually it responds as follows: in terms of syntax again the both hypotheses are valid, but theologically only the first ${ }^{14}$. The second opinion is not reconciling with the concept of the dogma of the creation of the universe from nothing - creatio ex nihilo.

\section{The historical context and the issue of syntax of the verse Gen 1, 1}

According to information theory, each of homo sapiens spoken word or sentence conveys a certain information. However, the amount of content depends mainly on two factors: the reliability of the

10 Cf. J.Lemański, Księga..., op. cit., p. 144-145; E.A. Speiser, Genesis: Introduction, Translation, and Notes, The Anchor Yale Bible 1, New Haven - London 2008, p. 9-12.

Cf. M. F. Rooker, Genesis..., op. cit., p. 316.

"[C]haos occurred in connection with the original creation [...]" (B. K. Waltke, Creation and Chaos, Portland 1974, p. 19).

Biblical

theology 
Biblical theology

information source of authority and the context. Thus, for example, synoptic forecast: "It will snow tomorrow", sounds different on 6 December in Vilnius and otherwise in Rome ${ }^{15}$.

Similarly, it is with the excerpt from Gen 1, 1. If, as indicated above, it is not possible to decide on the translation and interpretation solely based on linguistic arguments, then one must to grasp the context, which - as it seems - is not adequately evaluated over a translation or interpretation level. But here however it does not consider the literary context. It is of course very important ${ }^{16}$. This study takes aim at different context, namely the historical, which is also particularly useful in discovering the meaning of the biblical text, since the aptly recognized historical background of an episode clearly draws its message ${ }^{17}$.

Under what historical circumstances it was written the episode of Gen 1,1-2,4a? In this case, the opinions of researchers are relatively unanimous. For the experts the final editing of this fragment is dated to the times of the Babylonian captivity i.e., to the sixth century before Christ $^{18}$.

And what happened at that time is well known. The chosen nation lost the war with the Babylonians and thus had lost its political independence (cf. 2 Kings 25, 1-10). Although it must be admitted that this exile was not extremely difficult in comparison to that from the time of the Assyrian (VIII a.). King of Judah was still regarded as the heir of the throne of David. He had assured maintenance (cf. 2 Kings 24, 8-16; Jer 52, 31-34). Exiled people had been living together (cf. Ezek 1,$3 ; 2,15$ ). They were provided with food and with job (cf. Jer 29, 5-7). Neither the national culture, nor religion was banned (cf. Jer 29, 1.89.12-15). Some of them founded their company and even occupied

15 Cf. U. Eco, Atviras kūrinys. Forma ir neapibrèžtumas šiuolaikinèje poetikoje, Vilnius 2004, p. 116; D. Dzikiewicz, Zasady czytania Pisma Świętego, in D. Dzikiewicz - J. Witkowski (eds.), Józef Obrembski - kapłan wedtug serca Bożego, Wielcy Ludzie Wileńszczyzny 1, Wilno 2010, p. 112.

16 More on this see for example D. Dikevičius, Dèl $\operatorname{Pr} 1,1-3 A$ vertimo ir interpretacijos, in V. Balčius (ed.), Kunigas. Vilniaus Arkivyskupo Kardinolo Audrio Juozo Bačkio tarnystès penkiasdešimtmečiui, Vilnius 2011, p. 100-102.

17 Cf. R. E. Brown - S. M. Schneiders - M. Wojciechowski, Hermeneutyka biblijna, in R. E. Brown - J. A. Fitzmyer - R. E. Murphy (eds.), Katolicki komentarz biblijny, Prymasowska Seria Biblijna, Warszawa 2004², p. 1816.

18 "La sua redazione finale [...] risale all'epoca dell'esilio [...]" (G. von Rad, Genesi. Traduzione e commento, Antico Testamento 2/4, Brescia 1978, p. 76); "Il testo risale probabilmente al VI secolo a.C. e si rivolge a degli esulari" (W. Brueggemann, Genesi, op. cit., p. 44). 
high positions (cf. Dan 1, 1-7) ${ }^{19}$. The similar information also provides some archaeological artefacts ${ }^{20}$. So, there is nothing surprising in the fact that not all the exiles returned to Judea during the reign of King Cyrus II (559-529), whose edict allowed returning (cf. Ezra 1, 2-4; 6, $3-5)^{21}$. There established one of the most influential Jewish Diaspora.

Babylonian exile, however, was also seen in a negative light, especially in its initial phase. For many it was a real national catastrophe, primarily from the theological point of view (cf. Ps 79; 137; Lam). The chosen people found themselves in deep, not only political, but also theological crisis: God abandoned his people (cf. Isa 49, 14) ${ }^{22}$. Because the military beaten army was tantamount to the theological defeated God YHWH. And conversely, the victory of the army of Babylon was attributed to their national deity Marduk. In addition, the temple of Jerusalem was in ruins (cf. $2 \mathrm{Chr} 36,19$ ), the worship of God was broken and the priesthood has been scattered. And all these signs where indicating God's presence among his people. In short, everything was drowned in the big existential chaos.

Precisely, in such circumstances has been written the first chapter of Book Genesis. Its author (or authors), representing the so-called priestly tradition (P), concerned about different things, such as e.g., the celebration of the Sabbath (cf. Gen 2, 1-4a), but the most important were: YHWH, creation and chaos. His theological insight was brilliant. The Israel lost the previous signs of God's presence (the Promised Land, the temple of Jerusalem, the throne of David) - it's not a problem! Evidence of existing of YHWH are present through the creature - a sign par excellence. He, then, is the Creator of the universe. So, he was everywhere at home. Even on land that belongs to Israel's

19 Cf. J. D. Purvis - E. M. Meyers, Wygnanie i powrót. Od zburzenia Jerozolimy przez Babilończyków do odbudowy państwa żydowskiego, in H. Shanks (ed.), Starożytny Izrael. Od Abrahama do zburzenia świątyni jerozolimskiej przez Rzymian, Podręczniki Biblijne, Warszawa 2007, p. 297-311; P. Sacchi, Il giudaismo del Secondo Tempio, in G. Filoramo (ed.), Ebraismo, Economica Laterza 435, Roma - Bari 2007, p. 54-57.

20 Cf. P. Sacchi, Il giudaismo..., op. cit., p. 55; J. A. Soggin, Storia d'Israele. Introduzione alla storia d'Israele e Giuda dalle origini alla rivolta di Bar Kochbà, Biblioteca di cultura religiosa 44, Brescia 2002², p. 326-331.

$21 \quad$ Cf. J. D. Purvis - E. M. Meyers, Wygnanie..., op. cit., p. 317-319; P. Sacchi, Il giudaismo..., op. cit., p. 67-69; J. A. Soggin, Storia..., op. cit., p. 335-361.

22 "Abissalmente profonda fu la crisi [...]" (H. Küng, Ebraismo, Biblioteca Universale Rizzoli Saggi, Milano 20074, p. 119); "Con la caduta di Gerusalemme nel 587 a.C. si apre per l'ebraismo un periodo di crisi [...]” (P. Sacchi, Il giudaismo..., op. cit., p. 53); cf. L. Alonso Schökel, Isaiah, in R. Alter - F. Kermode (eds.), The Literary Guide to The Bible, London 1997, p. 174-180. 
enemies. He is God, who is not limited by any distance. Therefore, on the state of theological chaos is not worth sorrow and despair. For the one who arranged the primeval chaos at the beginning of creation (cf. Gen 1,1-2), is more able to give order to the existential chaos of the chosen people.

In other words, the author of the episode Gen 1,1-2, 4a did not care only about the cosmogony, but the issue of strengthening the faith of Israel ${ }^{23}$. And in such circumstances, the accent fell on the idea of creating the world of primordial chaos (cf. Gen 1, 1-2). The idea of creating the universe out of nothing (creatio ex nihilo) was not known to him. Such conclusions were reached by chosen peoples' theologians only in the second century BC (2 Macc 7, 28) ${ }^{24}$.

And this information sheds light on the work of the modern translator-exegete too. It rather tends to perceive the verse of Gen 1,1 as the phrases subsidiary. Because only then arises the idea of an utter and primeval chaos (cf. Gen 1,2) from the womb of which emerged a very good creation (cf. Gen 1, 3-31). In the sixth century before Christ, it was a source of renewal of faith for the chosen people, also today it provides consolation, because today's world is going through some chaotic situations on the various levels of life.

\section{Recapitulation}

This analysis allows drawing the following conclusions. Firstly, in the course of the exegesis' history it was not consensus regarding the meaning of the first sentence of the Hebrew Bible and there is no one either today. For someone, this is the main sentence (Gen 1, 1), for others dependent (Gen 1, 1-2). On the linguistic level, it is possible both. Secondly, if cannot resolve this issue only by means of linguistic tools, it would be worth to reach for help to the historical context of this text. And this shows that the episode of Gen 1,1-2, 4a was written at the time of the Babylonian exile. It was a time of major theological crisis, which was tantamount to a primordial chaos (Gen 1,2). Since the first was defeated by God Creator (Gen $1,3-2,1$ ), the second chaos will be defeated by God Saviour. In the light of this historical context Gen 1, 1 must see as the subordinate sentence. Thirdly, the above interpretation

\footnotetext{
23 "[I]l testo della creazione con cui la Bibbia comincia è stato formulato e riformulato come veicolo della fede di Israele" (W. Brueggemann, Introduzione all'Antico Testamento. Il canone e l'immaginazione cristiana, Strumenti Biblica 21, Torino 2005, p. 48). 
also has a pastoral value, because it aims to show God as the one who can master the existential chaos of every human being.

\section{WERSET RDZ 1, 1: ZDANIEM NADRZĘDNYM CZY DRUGORZĘDNYM? PRZYCZYNEK DO DYSKUSJI NAD SYNTAKSA PIERWSZEGO ZDANIA BIBLII HEBRAJSKIEJ}

Niniejszy artykuł został poświęcony zagadnieniu syntaksy wersetu Rdz 1, 1, należącego do najbardziej dyskutowanych ustępów Starego Testamentu. Opinie biblistów na jego temat są nadal podzielone. Zdaniem jednych jest to zdanie niezależne (status absolutus), drudzy natomiast utrzymują, że dany passus stanowi sekwencję podporządkowaną (status constructus) fragmentowi Rdz 1, 2-3. Na uzasadnienie swego stanowiska tak jedni, jak i drudzy przytaczają różnorodne argumenty: filologiczno-lingwistyczne, egzegetyczne, literackie, teologiczne. Nie są to jednak uzasadnienia przesądzające sprawę. Dlatego obecne opracowanie proponuje kolejną rację - kontekstualną. Kontekst jest bowiem nieodzownym elementem zrozumienia każdej jednostki literackiej. Tym razem nie chodzi wszak o kontekst literacki, lecz o ten historyczny, albowiem - czynnik sprawczy powstania całej perykopy $\mathrm{Rdz} 1,1-2$, 4a rzuca on również pewne światło na zagadnienie syntaksy wersetu $\operatorname{Rdz~1,1.~}$

Słowa kluczowe: Księga Rodzaju, syntaksa, zdanie nadrzędne, zdanie podrzędne, kontekst, stworzenie, chaos, niewola babilońska.

\section{Bibliography:}

1. Alonso Schökel L., Isaiah, in R. Alter - F. Kermode (eds.), The Literary Guide to The Bible, London 1997, p. 165-183.

2. Brown R. E. - Schneiders S. M. - Wojciechowski M., Hermeneutyka biblijna, in R. E. Brown - J. A. Fitzmyer - R. E. Murphy (eds.), Katolicki komentarz biblijny, Prymasowska Seria Biblijna, Warszawa 2004², p. 1786-1817.

3. Brueggemann W., Genesi, Strumenti Commentari 9, Torino 2002.

4. Brueggemann W., Introduzione all'Antico Testamento. Il canone e l'immaginazione cristiana, Strumenti Biblica 21, Torino 2005.

5. Childs B. S., Teologia biblica. Antico e Nuovo Testamento, Priemme Theologica, Casale Monferrato 1998.

6. Cotter D. W., Genesis, Berit Olam. Studies in Hebrew Narrative and Poetry, Collegeville 2003.

7. Davidson R. M., In the Beginning: How to Interpret Genesis 1, „Dialogue“, 1994, no. 6(3), p. $9-12$. 
Biblical theology

8. Dikevičius D., Dèl Pr 1, 1-3A vertimo ir interpretacijos, in V. Balčius (ed.), Kunigas. Vilniaus Arkivyskupo Kardinolo Audrio Juozo Bačkio tarnystès penkiasdešimtmečiui, Vilnius 2011, p. 95-104.

9. Dzikiewicz D., Zasady czytania Pisma Świętego, in D. Dzikiewicz - J. Witkowski (eds.), Józef Obrembski - kaptan wedtug serca Bożego, Wielcy Ludzie Wileńszczyzny 1, Wilno 2010, p. 101-118.

10. Eco U., Atviras kūrinys. Forma ir neapibrëžtumas šiuolaikinejje poetikoje, Vilnius 2004.

11. Hamilton V. P., Handbook on the Pentateuch. Genesis. Exodus. Leviticus. Numbers. Deuteronomy, Grand Rapids 1995.

12. Küng H., Ebraismo, Biblioteca Universale Rizzoli Saggi, Milano $2007^{4}$.

13. La Bibbia di Gerusaleme, Bologna $2000^{17}$.

14. Lemański J., Pięcioksiąg dzisiaj, Studia Biblica 4, Kielce 2002.

15. Lemański J., Księga Rodzaju. Rozdziaty 1-11. Wstęp, przektad z oryginatu, komentarz, Nowy Komentarz Biblijny Stary Testament I/1, Częstochowa 2013.

16. Łach S., Księga Rodzaju. Wstęp - przektad z oryginatu. Komentarz, Pismo Święte Starego Testamentu I/1, Poznań 1962.

17. Morant P., Die Anfänge der Menschheit. Eine Auslegung der ersten elf Genesis-Kapitel, Luzern 1960.

18. Purvis J. D. - Meyers E. M., Wygnanie i powrót. Od zburzenia Jerozolimy przez Babilończyków do odbudowy państwa żydowskiego, in H. Shanks (ed.), Starożytny Izrael. Od Abrahama do zburzenia światyni jerozolimskiej przez Rzymian, Podręczniki Biblijne, Warszawa 2007, p. 297-335.

19. Ricœur P., Apie vertima, Vilnius 2010.

20. Rooker M. F., Genesis 1:1-3: Creation or Re-Creation? Part 1, „Bibliotheca Sacra“, 1992, no. 149, p. 316-323.

21. Sacchi P., Il giudaismo del Secondo Tempio, in G. Filoramo (ed.), Ebraismo, Economica Laterza 435, Roma - Bari 2007, p. 53-123.

22. Soggin J. A., Storia d'Israele. Introduzione alla storia d'Israele e Giuda dalle origini alla rivolta di Bar Kochbà, Biblioteca di cultura religiosa 44, Brescia 2002².

23. Speiser E. A., Genesis: Introduction, Translation, and Notes, The Anchor Yale Bible 1, New Haven - London 2008.

24. Vawter B., Genesis, in R. C. Fuller (ed.), A New Catholic Commentary on Holy Scripture, Nashville - Camden - New York 1984², p. 166-205.

25. von Rad G., Genesis. A Commentary, Westminister 1973.

26. von Rad G., Genesi. Traduzione e commento, Antico Testamento 2/4, Brescia 1978.

27. Waltke B. K., Creation and Chaos, Portland 1974.

28. Wénin A., D'Adam à Abraham ou les errances de l'humain. Lecture de Genèse 1,1-12,4, Lire la Bible 148, Paris 2007. 